\title{
Improving Secondary Schools Management through Transformational Leadership Approach and Management Information Systems
}

\author{
Nnenna Ngozi Benwari (Ph.D.) \\ Department of Teacher Education, Faculty of Education, Niger \\ Delta University, Bayelsa State, Nigeria \\ Email:nenabenwari@yahoo.com \\ Boma Isabella Dambo (Ph.D.) \\ Department of Business Education, Faculty of Education, Rivers State \\ University of Science and Technology, Port Harcourt, Nigeria \\ Email:damboboma@yahoo.com
}

\section{Doi:10.5901/jesr.2014.v4n6p401}

\begin{abstract}
This paper examines the transformational leadership model and schools management information system (SMIS) as two change agents that can be applied to bring about improvement in the management of secondary schools in Nigeria. Transformational leadership applies certain principles such as personal autonomy of teachers and other staff, opportunities for leadership, communication, maximizing organizational outcomes which are also emphasized by a SMIS. Thus a SMIS needs to be driven by a transformational (visionary) leader leading to greater effectiveness and efficiency in secondary schools management in Nigeria. Recommendations are also made including retraining in leadership skills of school managers and providing necessary information and communications technologies.
\end{abstract}

Keywords: Leadership, transformational leadership, management information systems, schools management information systems.

\section{Introduction}

Management of the educational enterprise is a subject of great interest. This is because effective management of the educational system/schools is expected to bring about efficiency in the system. Highly effective leadership (by Directors of education, principals, head teachers etc.) would influence the teachers and other school personnel. This in turn would lead to production of a highly skilled manpower (students) and thus national development. This is a task that can be achieved through transformational leadership employing a schools management information system (SMIS).

Schools management involves different aspects such as personnel management, student records, infrastructure, financial records and general administration. The present system of schools management is based on sound record keeping making for continuity irrespective of changes in leadership. Records form the basis for governance, control and decision making. Billions of pages of information are generated each year by the different ministries, board, departments and units of education. These records can be in duplicates, triplicates etc. depending on the required number for each. Piles of documents are generated and finding information from past documents can be quite a daunting task. Even where computers are used to store information most school records and administration are still paper based. Durosaro (2004) has highlighted some problems of educational management in Nigeria to include gaps in policy, data, funding and quality assurance. He noted that that lack of accurate and timely data is an overriding factor and thus the bane of educational management in Nigeria. This has led to this study which seeks to seek for how the educational system can be managed more effectively and efficiently.

The purpose of the study is to find out how schools management can be improved through application of transformational leadership approach and management information systems in Bayelsa State. Thus the study hopes to find out ways to achieve quality and not just quantity education for national development; examine transformational and participative leadership in education and the use of management information systems in the school system as a means of increasing effectiveness and efficiency in the school system. 


\title{
2. Leadership
}

Leadership is very important in every human endeavor and has been defined in various ways. Leadership has been viewed to involve the ability to influence, direct and coordinate group activities in such a way that the people work willingly towards achieving the goals and objectives of the organization (Ukeje, Okorie and Nwagbara 1992). Leadership is very important in education. Educational leadership and management form very important aspects of school administration. While some scholars inadvertently use them interchangeably, there are some distinctions between the two words (Cuban, 1988 in Bush, 2007). He views leadership in terms of bringing about change, shaping the goals, motivations and actions of others and striving towards new goals. On the other hand, management is seen as an activity aimed at maintaining current organizational arrangements effectively and efficiently. While leadership is linked with stating values and purpose, management is linked with implementation. Thus the two work synergistically to achieve the objectives of education. West-Burnham, Bush, O'Neil and Glover (1999) have looked at leadership, management and administration as being interrelated. They view leadership as having to do with values, vision and mission; managementexecution, planning, organizing and deploying while administration- operational details. The functions are obviously intertwined and each one requires skills in the other two to function effectively.

Bush (2003) has classified leadership models alongside the corresponding management models as follows:

Table1: typology of management and leadership models (Bush 2003)

Management Model
Formal
Collegial
Transformational
Political
Subjective
Ambiguity
Cultural

\author{
Leadership Model \\ Managerial \\ Participative \\ Interpersonal \\ Transactional \\ Post-Modern \\ Contingency \\ Moral
}

Instructional

\section{Transformational Leadership}

Transformational leadership is one of the three leadership models linked to the collegial management on the table. It is seen as a shift from the older leader-centred leadership style to the newer process-centred leadership style. It is seen to be humanistic, virtue-driven and considerate of the needs of the employees. This would lead to greater job satisfaction. Better morale and higher productivity (Lowder 2009). The collegial management model to which transformational leadership is linked has the following characteristics-

Participatory democracy which allows all to express themselves

Everyone is granted opportunity to take part in the formal processes

Responsibility is assigned to all irrespective of their cadre in the system

People are also encouraged to take responsibility independently

Everyone is accorded respect and the atmosphere is relaxed

Eventually, individuals show commitment, belief and trust in the democratic process. model:

(Singh and Lokotsch 2005). They further capture the essence of transformational leadership in the following 


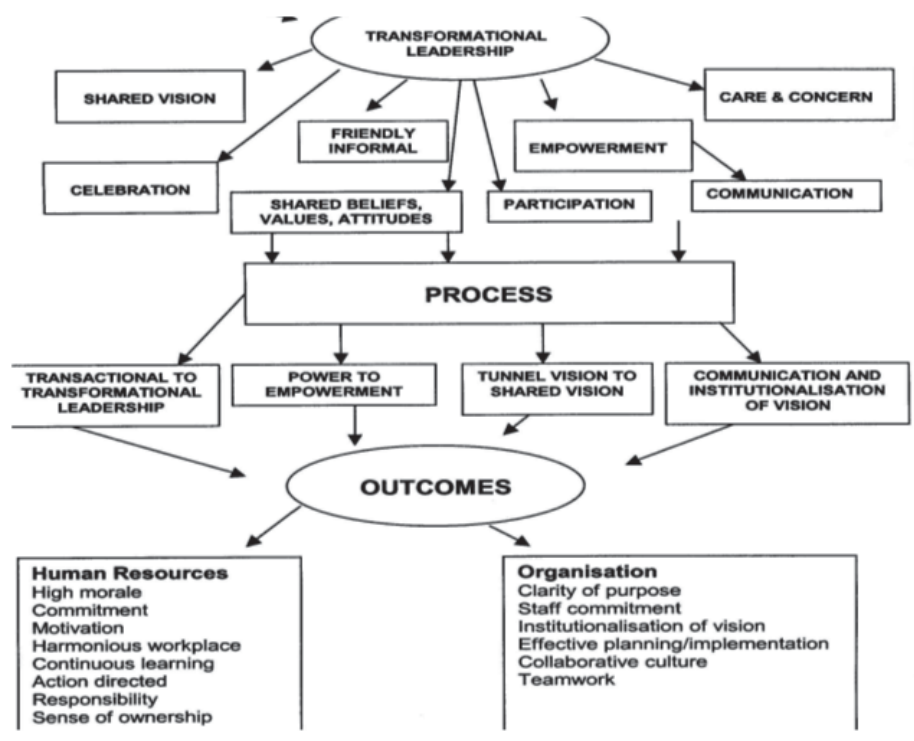

Fig 1. Transformational Leadership model (Singh and Lokotsch 2005)

Although some people may use transformational leadership as a catch phrase to score political points and gain acceptability, it is a process innovation and change which must lead to effectiveness and efficiency in educational/schools management. This must affect the curriculum and classroom instruction, school administration (including students, personnel and general data management), relationship between the schools and various stakeholders and management of facilities.

\section{Schools Management Information Systems}

A Management Information System (MIS) is a computerized database generated from and used to manage an enterprise. MIS was first developed for use in businesses but over the years has gained acceptability in other areas such as the educational system. MIS can be used at different levels of operation in an organisation to collect, process and store data. Large quantities of data can be processed quickly with the aid of computers converting data to information. Raw data entered into the computer can be translated into an output in form of information to help managers in decision making. (Babu, Singh and Sachdeva 2004 ).

MIS is broader than Enterprise Resource Planning (ERP), information systems and information technology management which are concerned with organizing information technology for all purposes. Most MIS are designed for specific aspects of the enterprise and they are designed to produce scheduled reports based on data from the database. Due to the availability of employee and other records the company or business can keep track of their performance and know where improvement is required. It also acts as a tool for planning.

MIS can be applied in the education/school system as Education Management Information System (EMIS) or Schools Management Information System (SMIS). This is a tool for schools management and administration and can include teaching and learning.

Schools Management Information System (SMIS) involves creating a large database which is then used for running the day to day activities of the school. All information about the school including student records, personnel records, financial records, teaching and learning materials, infrastructure which have been mentioned earlier are stored electronically in such a way that different authorized users have access to the information. Thus it is easy to exchange information within the school, generate reports to be sent outside the school and facilitate decision making. SIMS can be configured to serve the individual schools using a Local Area Network (LAN) or connected to a public server so that it can be accessed from outside the school. Where it is made public any staff with internet can connect to the SIMS and do their work from any location (Hi-Qacademy (2013), School Mangtaa (2013)). Parents and students can check students' 
results as well as news and updates. This would require a logon authorization. Automated emails and text messages can be sent to parents and guardian when the need arises.

\section{The Public School System}

Education has been noted in Nigeria as an instrument par excellence for national development (NPE 2004). Education is expected to equip the individual to be able live well in the society and contribute to its development. To achieve the laudable goals of Nigerian education proper and adequate management of the educational system. Education in Nigeria spans through pre-primary, primary, secondary to tertiary levels. Ther is also provision for adult, non-formal and special education. The state and local governments have responsibility for the secondary and primary schools while tetiary education is the responsibility of the federal government. The State Universal Basic Education Board (SUBEB) is directly in charge of the primary and junior secondar schools. Thus the headteachers must maintain communications with the SUBEB. The Senior Secondary Education Management Board is directly in charge of the senior secondary schools and the two must maintain continuous communication. The Ministry of Education oversees all levels of education.

Within the schools also, there are different cadre of staff including the headteachers, principals, their assistants, administrative staff, teachers. the learners are, of course, their parents who always need information about their children/wards.

Much is expected from educational leaders/managers. They should be able to uunderstand, interpret, modify and implement government policies. They must be able to make the schools functional basically. Aspects of schools management include:

Personnel management- including employment, salary, promotion, leave, transfer, training need, retirement.

Students records-including enrolment, attendance, continuous assessment, examination, class repetition, drop out, number of students per teacher.

Infrastructure- including buildings, facilities, equipment.

Financial records- funds, loans.

General administration- other school records, information dissemination, welfare.

All these require a lot of information exchange among the different stakeholders. Staff records for instance, always need to be updated and sent to the schools boards or ministry. This affects decisions and actions in the area of personnel management. Student records need to be updated and sent as well. Parents and guardians usually need information about their children/wards mostly with regard to their academic performance and general conduct.

Schools record managent is still mostly paper based with piles of documents being generated yearly and information not always readily available. There is a need therefore for a more innovative, effective and efficient approach.

\section{Benefits of Schools Management Information Systems}

Schools management information systems serve very useful purposes which are beneficial to the school. It could be used for both staff and students' management. It is used for storing records of academic and non-academic staff. Thus staff bio data and other information can be stored as well as staff work schedule. This way it is easy to monitor and track staff at each point in time. Staff employment, performance assessment, training/ retraining needs promotion and even time of retirement can be closely followed up. Teachers and other staff can sign in online as they come to school. Students attendance can also be taken and recorded using the school MIS. Other students' information ranging from their admission status, personal records, parents, address, phone numbers and email, continuous assessment records can be recorded and updated electronically. The school management system can be used for infrastructure and fees management, hostel space allocation and management, tracking students who have defaulted in payment of fees or other things. At each point in time finding any student information can be assessed at very short notice and within few minutes rather than hours or days. At the end of the term preparing and producing students' results also become very easy. The final examination scores are the only scores that need to be recorded because the continuous assessment scores have already been recorded. Rather than depending on manual calculations the school management system is used to prepare and print out the results. This is more time efficient and less prone to errors. Using the school management system different school documents can easily be managed and information such as memos, news bulletin, short messages (SMS), emails etc. can be generated automatically and sent to staff or parents as applicable. Relevant information can be made available to school administrators, personnel, parents and even the public.

Carnoy (2004) records that America has used computers to store student and personnel data since the seventies 
(1070's).school administrators had access to data from the different schools on their district computers through the internet. This makes it easier for basic decisions to be easily taken. Eventually schools management in many develop countries are computerized with emphasis being placed on using ICT to improve administration in the educational system. Schools management information systems create new possibilities for schools to connect directly with other schools and also to a wide array of information on the internet (Carnoy 2004). Schools can also access books, journals, pictures, videos and other materials which are used to enrich students' learning. Thus, the school management system is essential to effective school management.

\section{Transformational Leadership and Management Information Systems}

This paper believes that applying transformational leadership skills within a framework of school management information system would improve efficiency and effectiveness of the school system. Generally, transformation is linked to change and greater productivity. Transformational leadership and the management information system are also based the same principles. Transformational leaders believe in change, focus on long term goals and emphasize development (Bush 2007). They are great visionaries who inspire their followers to achieve the organizational vision. The transformational leader creates trust, admiration, loyalty and respect in the subordinates. The followers, in turn, being greatly motivated begin to put in more effort to the success of the system than even expected. Dulla and Nazarudin (2009) see the theories of transformational leadership as being the latest trend in the definition of leadership. Their summary of the characteristics of the transformational leader, as mentioned above, is in tandem with other authors such as Singh and Lokotsch (2005). Transformational leadership enhances opportunities for leadership development, increasing personal autonomy of teachers and supporting staff to maximize organizational outcomes.

The transformational leader is actually a change agent who brings about a radical difference in the running of the system for greater efficiency. He draws from other leadership models such as the bureaucratic, political and collegial to achieve better results. Such a leader as shown in the model above (fig. 1) emphasizes staff empowerment, participation, communication among other things. These are values encouraged and achievable through the schools management information system. Applying the transformational leadership style alongside the schools MIS is bound to bring about greater effectiveness and efficiency, thus improving management of secondary schools in Nigeria.

\section{Conclusion}

This paper has looked at transformational leadership model which is seen as the latest trend in leadership. This leadership model is visionary in approach and encourages change leading to greater efficiency. To better harness this leadership model, this paper has also looked at the application of a schools management information system. This involves the use of specialized ICTs with internet in carrying out the day to day management of school activities. These include data management, timetabling, hostel allocation, fees payment, results and information to parents and other stakeholders. This way many bureaucratic bottlenecks can be surmounted; information is readily available leading to prompt and informed decision making; parents can be better informed about the general behaviour/performance of their children; results can be more accurately computed and published timely. This is expected to produce greater efficiency and improvement in the secondary schools.

\section{Recommendations}

Based on the foregoing the following recommendations are made:

1. Secondary school managers should undergo retraining on principles and application of transformational leadership style.

2. Staff of secondary schools should be trained in the use schools management information system.

3. The schools ICT policy should be fully implemented.

4. Nigerian secondary schools should be provided with ICT infrastructure for implementing the schools management information system. 


\section{References}

Bush, T. (2007). Educational leadership and management: theory, policy and practice. South African Journal of Education 27 (3) 391 406.

Carnoy, M. (2004). ICT in education: Possibilities and challenges. Retrieved 6/11/2013 from www.uoc.edu/inaugural04/ dls/eng/carnoy1004.pdf.

Dulla, J. J and Nazarudin M. N. (2009). Headmaster's transformational leadership and teacher's organizational commitment in primary schools

Durosaro, D. O (2004). Crucial issues in the management of primary education in Nigeria in Fagbamiye, E. O, Babalola, J. B. Fabunmi, $\mathrm{M}$, and Ayeni, $\mathrm{A}$. $\mathrm{O}$ (Eds). Management of primary and secondary education in Nigeria. Nigeria: A publication of Nigerian Association for Educational Administration and planning. Also available on www.unilorin.edu.ng/publications /durosaro/ management

Hi-Qacademy (2013). School management system-Advantages. Retrieve 11/11/2013 from www.hi-qacademy.com/products Isms/advantages.

Lowder, T. M. (2009). The best leadership model for organizational change management: transformational verses servant leadership.

School Mangtaa (2013). Advantages of school management system. Retrieved 11/11/2013 from www.schoolmangtaa.com/site IAdvantages.aspx.

Singh, P and Lokotsch, K. (2005). Effects of transformational leadership on human resource management in primary schools. South African Journal of Education, 25(4), 279-286.

Ukeje, B. O., OKorie, N. C. and Nwagbara, U. A. (1992). Educational administration: Theory and practice. Owerri: Total Publishers. The Embassy of the Federal Republic Nigeria, South Korea (2013). Education in Nigeria. Thrived 19/09/13 from www.nigerianembassy.or.kr/nigeria/education.asp. 